\title{
Die baie stemme van Adam Small
}

\begin{tabular}{|c|c|}
\hline \multicolumn{2}{|l|}{$\begin{array}{l}\text { Book Title: } \\
\text { Adam Small: D } \\
\text { dramaturg-' } r \\
\text { Book Cover: }\end{array}$} \\
\hline 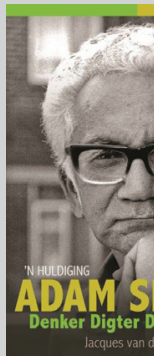 & ILL \\
\hline \multicolumn{2}{|c|}{$\begin{array}{l}\text { Author: } \\
\text { Jacques van der Elst }\end{array}$} \\
\hline \multicolumn{2}{|c|}{ ISBN: } \\
\hline \multicolumn{2}{|c|}{$\begin{array}{l}\text { Publisher: } \\
\text { Protea Boekhuis, 2017, R200* } \\
\text { *Book price at time of review }\end{array}$} \\
\hline \multicolumn{2}{|l|}{ Review Title: } \\
\hline \multicolumn{2}{|c|}{$\begin{array}{l}\text { Die baie stemme van Adam } \\
\text { Small }\end{array}$} \\
\hline \multicolumn{2}{|c|}{$\begin{array}{l}\text { Reviewer: } \\
\text { Fanie Olivier }{ }^{1} \text { (]) }\end{array}$} \\
\hline $\begin{array}{l}\text { Affiliation: } \\
{ }^{1} \text { Emeritus Pro } \\
\text { University of } \\
\text { Thohoyandol }\end{array}$ & $\begin{array}{l}\text { fessor, } \\
\text { lenda, } \\
\text { South Africa }\end{array}$ \\
\hline \multicolumn{2}{|c|}{$\begin{array}{l}\text { Corresponding author: } \\
\text { Fanie Olivier, } \\
\text { olivierf@mweb.co.za }\end{array}$} \\
\hline \multicolumn{2}{|c|}{$\begin{array}{l}\text { How to cite this book review: } \\
\text { Olivier, F., 2019, 'Die baie } \\
\text { stemme van Adam Small', } \\
\text { Literator 40(1), a1521. https:// } \\
\text { doi.org/10.4102/lit.v40i1.1521 }\end{array}$} \\
\hline \multicolumn{2}{|c|}{$\begin{array}{l}\text { Copyright: } \\
\text { (c) 2019. The Authors. } \\
\text { Licensee: AOSIS. This } \\
\text { is licensed under the } \\
\text { Creative Commons } \\
\text { Attribution License. }\end{array}$} \\
\hline \multicolumn{2}{|l|}{ Read online: } \\
\hline 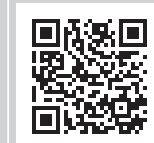 & $\begin{array}{l}\text { Scan this QR } \\
\text { code with your } \\
\text { smart phone or } \\
\text { mobile device } \\
\text { to read online. }\end{array}$ \\
\hline
\end{tabular}

Die toekenning van die Hertzogprys vir Drama aan Adam Small in 2012 het hierdie belangrike figuur in die Afrikaanse letterkunde uiteindelik weer op die voorgrond geplaas, nadat hy in alle opsigte vir dertig jaar eintlik van die toneel verdwyn het.

Veertig jaar na sy laaste Afrikaanse digbundel, die foto-en-versboek Oos wes tuis bes Distrik Ses (saam met Chris Jansen), verskyn 'n nuwe bundel, die lywige Klawerjas, net om ons daaraan te herinner dat hy eintlik as digter die eerste stem van die Sestigers was. Maar 'n ander stem, 'n Kaapse stem, 'n bruin stem, 'n swart stem.

En drie jaar na Klawerjas is die 'dice' vir oulaas gegooi.

Toe die Suid-Afrikaanse Akademie vir Wetenskap en Kuns besluit het om 'n nuwe reeks publikasies aan die gang te sit, huldigingsbundels rondom Suid-Afrikaanse Hertzogpryswenners, was dit seker nie minder as reg dat eerbetoon aan een van die mees miskende skrywers uit ons taalgebied dit sou inlui nie.

Hierdie publikasie, Adam Small: Denker, digter, dramaturg - 'n huldiging, saamgestel deur Jacques van der Elst, verskyn in 2017 en belig verskillende fasette van Small se lewe en sy werk. Van der Elst plaas in die Voorwoord die boek binne daardie konteks en gee kortliks 'n samevatting van die verskillende bydraes. Die leser wat nie van die begin tot die einde wil lees nie - en dit hoef ook nie - kan dus besluit waar sy of haar belangstelling lê.

Hoewel dit in 'n akademiese omgewing verskyn en sekerlik 'n geleerde baadjie dra, is die boek besonder toeganklik en het die 11 bydraers daarin geslaag om deur die verskillende invalshoeke vir die lesers 'n beeld van die skrywer te gee.

Die publikasie begin met twee hoofstukke rondom die lewe van Adam Small: 'n deeglike biografiese oorsig deur Erika Terblanche en "n Persoonlike geskiedenis' deur Abraham H. de Vries. De Vries se stuk is 'n heerlike verslag van 'n vriendskap wat in die donker dae van Apartheid begin en waarin die hele verloop van die Afrikaanse letterkunde sedert daardie tyd betrek word.

Jacques van der Elst se hoofstuk oor 'Adam Small en die Hertzogprys' sluit by die biografiese gedeelte aan en behoort daarom ook sekerlik as die derde hoofstuk te verskyn het. Die omstredenheid rondom hierdie toekenning in 2012 is seker nou al vergete; daarom is dit belangrik dat daar nou behoorlik hieraan aandag gegee word.

Die 'denker'-gedeelte van die boek word deur drie bydraes verteenwoordig, waarvan Hein Willemse se indringende literêr-dialektiese lesing van die lang gedig 'Vryheid' ook tuisgebring moet word onder die 'digter'-komponent. Soos die volledige titel van sy artikel aandui, is dit 'n verkenning van hoe die insident van die skrywer se swanger vrou wat op die bus móét staan omdat sy 'nie-blank' is, op baie vlakke neerslag kry - ook rondom die wyse waarop taal gebruik word.

Steward van Wyk sluit by die gebruik van Afrikaans, Standaardafrikaans en Kaaps aan wanneer hy wys hoe Small se identiteitskonstrukte voortdurend verskuif soos wat die Suid-Afrikaanse gemeenskapspatrone ook verander. Van Wyk wys daarop dat dit nie op 'n soort wispelturigheid by Small dui nie, maar die resultaat is van 'n deurleefde kritiese lewenshouding.

Die derde artikel oor Adam Small as denker ('n mens moet steeds onthou dat hy as filosoof opgelei is) is in sekere opsigte die boeiendste: 'Adam Small en sy pleidooi vir geregtigheid:' $n$ Gevallestudie'. Antoinette Lombard en Rinie Schenk gee ' $n$ uiteensetting van Small se benadering tot maatskaplike werk en in watter opsig hy 'n deurslaggewende rol gespeel het om die Departement Maatskaplike Werk by die Universiteit van Wes-Kaapland aan die voorpunt van die herwaardering van 
welsynswerk binne die groter filosofiese en sosio-politieke konteks te plaas. Dit is 'n belangrike hoofstuk omdat daar so min van hierdie faset van Small se lewe bekend is; iets wat ook verduidelik waarom hy vir soveel jare as skrywer uit die openbare oog verdwyn het.

Kanna hy kô hystoe word met reg as die belangrikste werk van Small as toneelskrywer beskou en twee van die drie hoofstukke oor hom as 'dramaturg' word aan hierdie drama gewy. Albei is met nuwe invalshoeke geskryf. Marisa Keuris neem in haar 'Herinneringe en herbesinnings' bestek op van die opvoeringgeskiedenis van die drama en die problematiek van akteur, karakter en taal wat daarmee saamgeloop het.

Jacomien van Niekerk se 'Brechtiaanse vervreemding in Kanna hy kô hystoe - 'n Poging tot opvoeranalise' sluit hierby aan, maar kyk wat in twee radiodrama-aanbiedings van die teks gebeur het. Die neerslag van Brecht se opvattings in hierdie drama is bekend, en word hier deeglik betrek by 'n beskouing oor wat rondom 'n produksie gebeur waar die toeskouer en die akteur se verhouding vervang word.

Michael le Cordeur kyk na die ander bekende Small-drama, Krismis van Map Jacobs, met ' $n$ ander bril soos die titel van sy bydrae duidelik maak: 'Die aktualiteit van Krismis van Map Jacobs met verwysing na die tema van bendekultuur en Kaaps as onderrigtaal'. Hierdie drama is baie wyer as Kanna ons kô hystoe bekend omdat dit 'n voorgeskrewe skoolteks is. Dit is daarom goed dat dit ook in hierdie huldigingsbundel aandag geniet. Met die verhouding tussen letterkunde en die maatskappy en die verkenning van die bendekultuur, sluit Le Cordeur by Adam Small die maatskaplike werker aan, en met die gedeelte oor Kaaps as onderrigtaal, bevestig hy weereens die belangrike rol wat Small sedert Kitaar my kruis gespeel het om hierdie streekstaal as volwaardige kommunikasiemedium te vestig.

Bernard Odendaal gee vroeg in die boek 'n oorsig van 'Adam Small se literêre status vóór en ná 1990 - met klem op sy digterskap'. Dit is 'n stewige ondersoek (kyk maar na die bronnelys) waarin die jaar 1990 niks met Small se eie produktiwiteit te make het nie, maar hoe die veranderende politieke werklikhede neerslag in nuwe waardering by 'n volgende geslag skrywers en akademici vir Small se poësie gekry het, of ten minste vir die wyse waarop hy in Kaaps daarmee omgegaan het. Dit, voer Odendaal aan, is 'n vorm van kanonisering wat nie geïgnoreer kan word nie.

Op 'n persoonlike vlak, soos dié van Abraham $\mathrm{H}$ de Vries, maar tog heel anders, is die blik van buite deur die Nederlandse taalkundige Willy Martin. Hy skets kortliks sy eie kennismaking met en vervreemding van Afrikaans, toon aan watter rol Vernon February in die ommekeer in sy houding gespeel het en hoe sy belangstelling in Afrikaans hom uiteindelik daartoe gebring het om, naas sy sentrale rol in die totstandkoming van die monumentale woordeboek Anna, ook gedigte van Small na Nederlands te vertaal.

Daar is ook 'n stuk of agt interessante foto's in die publikasie en 'n redelik uitgebreide bibliografie oor en rondom Small, wat deur Bettina Wyngaard saamgestel is.

Adam Small: Denker, digter, dramaturg - 'n huldiging is ' $\mathrm{n}$ publikasie waaraan daar moeilik reg in 'n korterige resensie geskied kan laat word. Die boek self kan ook maar net aan die komplekse en ryk bydrae van Small vat-vat. Dit skep terselfdertyd die maatstaf waaraan ander boeke in hierdie huldigingsreeks gemeet gaan word. 